duration of two years, the Department of Equal Opportunities is obliged to organize a competition for awarding an annual advertising prize that best represents the image of a woman during the year.

In addition, the Department of Equal Opportunities is currently coordinating the development of an action plan to combat sexual and gender-based violence, which will be aimed, in particular, at increasing the level of prudence and awareness of media operators in order to ensure that information and (commercial) communication respects gender representation and, in particular, the image of women.

Actual today are the programs developed by professionals who have worked on the issue of gender equality in journalism and advertising for many years, and are distributed at the national level with the help of posters, television advertising and advertising programs.

Thus, the media can slow down or accelerate progress towards achieving gender equality, influencing the formation of perceptions, opinions, and public behavior.

\title{
References
}

1. https://rm.coe.int/1680590557

2. https://ec.europa.eu

3. https://www.sociology.org/care-bears-vs-transformers-genderstereotypes- in-advertisements/

DOI: http://doi.org/10.31617/k.knute.2019-03-19.13

\section{CARELESS ADVERTISEMENT ABOUT «DELICIOUS» FOODSTUFFS OF UKRAINIANS}

\author{
Shapoval S. \\ Candidate of sciences (PhD), Associate Professor, \\ Vice-Rector on scientific and pedagogical work \\ Kyiv National University of Trade and Economics, Ukraine \\ Radchenko, A. \\ Candidate of sciences (PhD), Associate Professor \\ Department of Trade and Expertise of Goods \\ Kharkiv State University of Food Technology and Trade, Ukraine
}

Keywords: advertising products, media online advertising, food products, careless advertising.

Advertising activity in Ukraine, which is an integral part of a market economy, is regulated by the Law of Ukraine «On Quality and Safety of 
Food Products and Food Raw Materials». Article 1 of this Law states that «advertising is information about a person or a product distributed in any form and in any way intended to form or support the awareness of consumers of advertising and their interest in such persons or goods» [3].

Advertising follows a modern person everywhere, moving in the hearts and minds of people from television screens, from the background of information publications, from billboards and citylights on the streets, in the subway and other modes of transport. It is an integral part of the free market and prompts the consumer to purchase the appropriate advertised product. A lot of consumers believe to every seen billboard and scroll or heard slogan from TV and then argue when the product doesn't coincide with the presented product qualities. And it happens quite often, even when the advertisement is made by renowned copywriters with loud names.

Advertising is also a special area of journalism that has a link with its infrastructure. Therefore, it obeys the same rules and laws as its other layers. The concept of the effectiveness of advertising can be disclosed as a combination of its effectiveness and efficiency, that is, the impact of advertising material on the consumer, and as a result - on the status of the advertiser. The effectiveness of advertising is also linked to the ethics of advertising message. Just a few years ago, numerous mass media widely advertised the services of the MMM's financial pyramid, and we all know what it ended up for its consumers. However, even today, the editorial staff of newspapers and various printed advertising media publishing the advertising materials makes a statement that the editorial board is not responsible for its content, despite the fact that in accordance with the Law of Ukraine «On protection from unfair competition», the dissemination of information that misleading is forbidden [2].

A well-known theoretician of journalism at the Lviv national University named after Ivan Franko, Zdorovega, wrote that «journalistic work is not just a skill to write a note or an article literally, although these basics must be mastered, but a peculiar way of perceiving the world, a way of seeing reality, a way of thinking and a worldview, a mode of existence and awareness of yourself in an uneasy life» [4] .

In the XXI century an undeniable world trend was the decline in the curiosity of reading printed media, which has not missed Ukraine. Though advertising texts are promoted, different newspaper genres are used: interviews, articles, reports (except for pure advertisement). Still, it is very difficult to compete with the Internet-press sites. Thus, for the first half of 2018, the market of the media Internet advertising amounted to 1.1 billion UAH, which is $32 \%$ higher than the figure for the same period in 2017 , the 
share of direct sales in the media advertising market during this period amounted to $56.1 \%$ [1].

Nowadays, there are many formulas for advertising texts. Any one of them is interested and accordingly the desire to buy a product or service. Experts assert that the presence of increased emotionality undermines the effectiveness of advertising, because the consumer may feel insecure, and therefore, will not trust it. There are often cases when the advertisement contains incomplete or inaccurate information about food products that manipulates the consciousness of consumers. For example, many manufacturers of sunflower oil focus consumers attention on the label «does not contain cholesterol», which it can not be. But the manufacturer represents his product as more qualitative and more useful. Or, often use the inscription «Hurry, quantity of goods is limited», which should convince the consumer to buy this product faster.

A typical method used in advertising is the positioning of a food product as created on the basis of natural ingredients, or has some special dietary or even therapeutic properties. In this case, of course, there is no information about its actual composition, namely, the presence of vegetable fats, soy, dyes and flavors, other additives that are harmful to health. For example, they tell the consumer about «raspberry yoghurt» or «peach yogurt», although in fact there is not much fruit there, and the illusion of their presence is created due to aromatic additives, which are often harmful to health. There are cases when unscrupulous advertisement plays even indirectly, but a significant role in appearance of serious health problems. Diseases are caused by food ingredients that are dangerous to health and are aggressively advertised. However, the cases of domestic court practice, when the court, on the basis of medical and other examinations, recognized the direct relationship between the illness of the consumer and the use of a dangerous product, are unknown to the authors. At the same time, the judicial system of the western countries is very sensitive to such cases. For example, in the United States recently there was a case in which the consumer proved in court that his oncological illness arose from drinking water that had been contaminated by toxic substances from chemical production nearby and received compensation of several million dollars [5].

Thus, we have reviewed a number of examples of unfair advertising in the food industry. We believe that it is impossible to attract consumers' attention and provide them with food with the help of advertising in any way.

It is important to respect the consumer, to turn back the belief in advertising healthy food products and that their consumption will strengthen the health of the nation, immunity will increase considerably, 
work efficiency will increase and in general reserves of the organism will expand and life of the population of Ukraine will lengthen.

\title{
References
}

1. Vartist internet-reklamy zrosla na tretynu [Electronic resource]. - Access mode: https://1news.com.ua/ukraine/vartist-internet-reklami-zrosla-natretinu.html

2. Zakon Ukrayiny «Pro zakhyst vid nedobrosovisnoyi konkurentsiyi» № 236/96-VR. (Vidomosti Verkhovnoyi Rady Ukrayiny, 1996, № 36, st. 164). Nova redaktsiya iz zminamy vid 03.03.2016.

3. Zakon Ukrayiny «Pro reklamu» №270/96-VR. (Vidomosti Verkhovnoyi Rady Ukrayiny, 1996, № 39, st. 181). Nova redaktsiya iz zminamy vid 26.07.2018.

4. Zdoroveha V.Y. Teoriya i metodyka zhurnalist•s'koyi tvorchosti: Pidruchnyk. - 2-he vyd., pererob. i dopov. / V.Y. Zdoroveha. - L'viv: PAIS, 2004. $-268 \mathrm{~s}$.

5. Maslo bez kholesterynu, kava vid artrytu ta «dytyacha» kovbasa. Yak ne potrapyty na hachok «apetytnoyi» reklamy zdorov"ya natsiyi [Electronic resource]. - Access mode: https://glavcom.ua/country/health/maslo-bezholesterinu-kava-vid-artritu-ta-dityacha-kovbasa-yak-ne-potrapiti-nagachok-apetitnoji-reklami-534492.html

DOI: http://doi.org/10.31617/k.knute.2019-03-19.14 INSTAGRAM: TEST WEB VERSIONS OF DIRECT POSTS

\author{
Shylo B. \\ University Grenoble Alpes, France
}

Keywords: mobile devices, Instagtam, tests, direct messages.

Today the question becomes quite relevant and special attention is paid to mobility. More and more people are reading the news on their mobile phones. News producers are concerned about the quality of the presentation of interactive content, broadcast on mobile devices.

The media uses a website design that adapts to the device you are using. Mobile devices encourage the use of large amounts of numerical data in everyday life, for example, applications that track our performance or calorie consumption. 